Submitted to Journal of Chemical Physics

\title{
MULTIPHOTON DISSOCIATION PRODUCTS FROM \\ HALOGENATED HYDROCARBONS
}

RECEIVED LAVRENCE

Aa. S. Sudbo, P. A. Schulz, E. R. Grant, Y. R. Shen and Y. T. Lee

EV LABORATORY

DEC 121977

November 1977

LIBPARY AND

DOCUMENTS SECTION

Prepared for the U. S. Department of Energy under Contract W-7405-ENG-48

\section{For Reference}

Not to be taken from this room

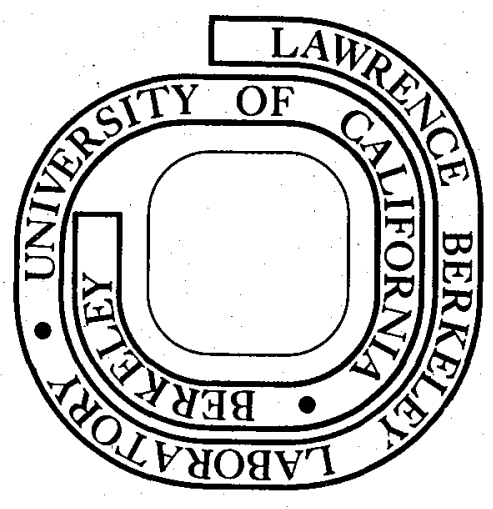





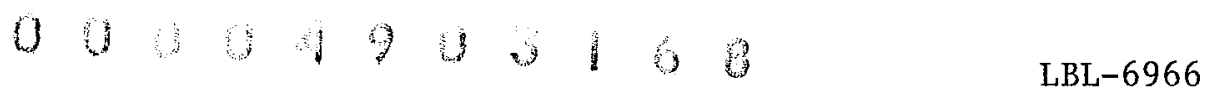

\title{
MULTIPHOTON DISSOCIATION PRODUCTS FROM HALOGENATED HYDROCARBONS
}

\author{
Aa. S. Sudbo, ${ }^{\dagger}$ P. A. Schulz, ${ }^{\dagger}$ E. R. Grant,,$^{*}$ \\ Y. R. Shen ${ }^{\dagger}$ and Y. T. Lee ${ }^{*}$ \\ Materials and Molecular Research Division \\ Lawrence Berkeley Laboratory \\ University of California, Berkeley, California 94720
}

November 1977

The recent interest in multiphoton dissociation (MPD) of polyatomic molecules has revealed quite a bit of confusion as to what the major dissociation channels of some molecules are, ${ }^{1-5}$ and whether the dissociation process can be described by a statistical, e.g., RRKM, theory of unimolecular reactions..$^{4-8}$ In a gas cell experiment an experimenter often finds great difficulties in answering questions such as: do vibrationally excited molecules react with one another, how do reactions involving free radicals produced in the dissociation proceed, can these radicals decompose further in the presence of the laser field, and does the detection method used actually probe the primary dissociation channe1.

Using the molecular beam setup previously described, ${ }^{9}$ we have overcome most of these difficulties. We have studied MPD of a number of compounds, mainly halogenated methanes, ethanes and ethylenes, and identified their major dissociation channels. To identify an MPD

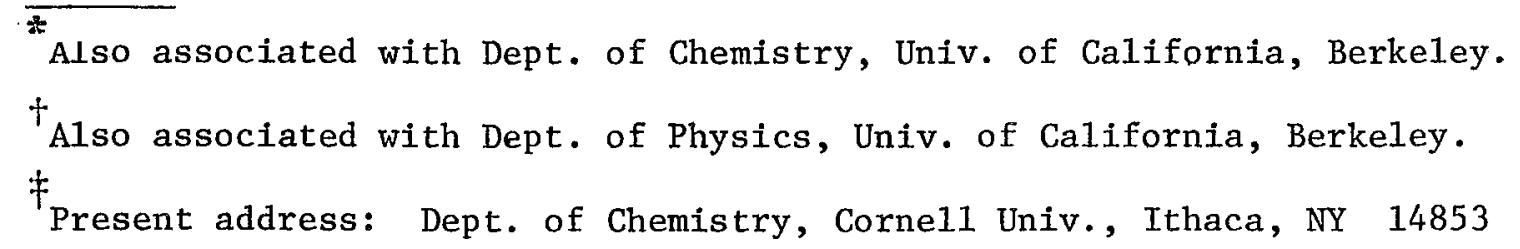


product, we realize that a unique set of ratios between mass spectrometer signals of various ion fragments must first be established for a given molecular species or radical, and preferably the velocity distributions of the dissociation products should be measured and checked for consistency. In our setup, we could measure both angular and time-of-flight distributions for the fragments, and perform this check. The low density of molecules in the beam and the extremely low duty cycle in our experiment prevented us from observing the competing minor channels which have very small branching ratios $(<0.1)$.

In Table 1 we give a list of the molecules we haye studied, together with the results and a few parameters describing the experimental conditions. The purpose of heating the nozzle in some of the experiments was to increase the hot-band absorption and thus shift the absorption frequency to a value more easily attainable by our $\mathrm{CO}_{2}$ TEA laser. A more extensive presentation and analysis of our data will be given elsewhere; here we present only the qualitative results.

The simplest compounds studied were the members of the $\mathrm{CF}_{3} \mathrm{X}$ series, $\mathrm{X}=\mathrm{Cl}, \mathrm{Br}, \mathrm{I}$. The fragments of MPD were $\mathrm{CF}_{3}$, detected in the mass spectrometer mainly as $\mathrm{CF}_{2}{ }^{+}$and $\mathrm{CF}^{+}$, both with identical velocity distributions, and $\mathrm{X}$ with a different distribution. The velocity distributions of $\mathrm{CF}_{3}$ (detected as $\mathrm{CF}_{2}^{+}$and $\mathrm{CF}^{+}$) and $\mathrm{X}$ were correlated by the conservation of linear momentum in the dissociation 
process. The ratios between the mass spectrometer signals of $\mathrm{CF}_{3}{ }^{+}$, $\mathrm{CF}_{2}^{+}$and $\mathrm{CF}^{+}$were determined for each of the three cases. The ratios were independent of laser energy fluence and the product translational energy (within the stated uncertainties). With an ionizing electron energy of $200 \mathrm{eV}$ in the mass spectrometer, the ratios were

$$
\begin{array}{lccc}
\mathrm{X} & \mathrm{CF}_{3}^{+} & \mathrm{CF}_{2}^{+} & \mathrm{CF}^{+} \\
\mathrm{C} 1 & 0.2 \pm 0.2: 2.4 \pm 0.2: 1.0 \\
\mathrm{Br} & 0.2 \pm 0.3: 2.4 \pm 0.1: 1.0 \\
\mathrm{I} & 0.7 \pm 0.2: 2.6 \pm 0.2: 1.0
\end{array}
$$

The species $\mathrm{CF}_{2} \mathrm{Cl}_{2}, \mathrm{CF}_{2} \mathrm{Br}_{2}, \mathrm{C}_{2} \mathrm{HCl}_{3}$ also mainly dissociate through the rupture of a carbon halogen bond. Molecular elimination forming $\mathrm{CF}_{2}+\mathrm{Cl}_{2}$ and $\mathrm{CF}_{2}+\mathrm{Br}_{2}$ from $\mathrm{CF}_{2} \mathrm{Cl}_{2}$ and $\mathrm{CF}_{2} \mathrm{Br}_{2}$ were found not to be the major dissociation channels. ${ }^{1,2}$ For $\mathrm{CFCl}_{3}$, however, as previously reported for $\mathrm{SF}_{6},{ }^{8}$ we observed an ionization pattern that depended on laser energy fluence and the product translational energy. At moderate $\left(\approx 5 \mathrm{~J} / \mathrm{cm}^{2}\right)$ laser energy fluence the products could be identified as $\mathrm{CFCl}_{2}$ and $\mathrm{Cl}$, through the observation of the ions $\mathrm{CFCl}_{2}{ }^{+}$and $\mathrm{Cl}^{+}$. Our result agreed with Hudgens' observation, ${ }^{1}$ but not with Dever and Grunwald's conclusion of $\mathrm{CFCl}_{3} \rightarrow \mathrm{CFC1}+\mathrm{Cl}_{2} \cdot{ }^{4}$ However, at higher energy fluence $\left(>20 \mathrm{~J} / \mathrm{cm}^{2}\right)$, products with very high translational energy showed appreciably less relative fraction of $\mathrm{CFCl}_{2}{ }^{+}$as compared to $\mathrm{CFCl}^{+}$, indicating that $\mathrm{CFCl}_{2}$ dissociated further to form $\mathrm{CFCl}$ and $\mathrm{Cl}$. No $\mathrm{F}^{+}$ or $\mathrm{Cl}_{2}{ }^{+}$could be detected throughout this experiment.

Similar analysis has been performed for the other molecules listed in Table 1. Here we will just briefly comment on the general 
features we have observed. A number of our systems showed hydrogen halide (i.e., HC1) elimination (in some cases expected on the basis of observed pyrolytic unimolecular reactions). The translational energy distribution of $\mathrm{HCl}$ in all cases, with the exception of $\mathrm{CHCl}: \mathrm{CF}_{2}$, indicated an exit potential energy barrier of the order of a few $\mathrm{kcal} / \mathrm{mole}$.

Especially interesting cases are some of the compounds containing two carbon atoms, because we observed competing dissociation channels. They were inferred on the basis of observation of fragments in the mass spectrometer which could not have all been present if there were only one channel, and also from their unique velocity distribution. Table I lists some of the observed fragment ions for these molecules. None of our observations seemed to contradict the assumption that dissociation always proceeds through the channel(s) with the lowest dissociation threshold, i.e., the endoergicity plus exit potential energy barrier.

In conclusion we have found that our experimental results, including the velocity distributions of fragments which will be reported elsewhere, strongly support the idea that multiphoton dissociation of molecules produces fragments mainly through the lowest-energy dissociation channe1, as one would expect for molecules with randomly distributed excitation energy. Our data is not as yet fully analyzed, but so far, we have not seen any evidence that the process is qualitatively different from what can be adequately described by a statistical theory of unimolecular reactions. 
$-5-$

This work was done with support from the U. S. Department of Energy • 
REFERENCES

1. J. W. Hudgens, preprint, submitted to J, Chem. Phys .

2. D. S. King and J. C. Stephenson, Chem. Phys, Lett. 51,48 (1977).

3. S. Mukame1 and J. Ross, J. Chem. Phys. 66, 5235 (1977).

4. D. F. Dever and E. Grunwald, J. Am. Chem. Soc. 98, 5055 (1976),

5. I. Oref and B. S. Rabinovitch, preprint, submitted to J. Phys. Chem.

6. J. G. Black, E. Yablonovitch, N. Bloembergen and S. Mukame1 in "Multiphoton Processes" ed. by J. M. Eberly and P. Lambropoulos (Wiley, New York, 1977).

7. J. L. Lyman, J. Chem. Phys, 67, 1868 (1977),

8. E. R. Grant, P. A. Schulz, Aa. S. Sudbo, Y, T, Lee and Y, R. Shen, in "Multiphoton Processes" ed. by J. H. Eberly and P. Lambropoulos (Wiley, New York, 1977).

9. M. J. Coggiola, P. A. Schulz, Y. T. Lee and Y. R. Shen, Phys. Rev. Lett. 38, 17 (1977). 
Table 1

Molecule, Fragments and Observed Ions

$\mathrm{CF}_{3} \mathrm{Cl} \rightarrow \mathrm{CF}_{3}+\mathrm{Cl}\left(\mathrm{Cl}^{+}, \mathrm{CF}_{2}^{+}\right)$

$\mathrm{CF}_{3} \mathrm{Br} \rightarrow \mathrm{CF}_{3}+\mathrm{Br}\left(\mathrm{Br}^{+}, \mathrm{CF}_{2}^{+}\right)$

$\mathrm{CF}_{3} \mathrm{I} \rightarrow \mathrm{CF}_{3}+\mathrm{I}\left(\mathrm{I}^{+}, \mathrm{CF}_{2}^{+}\right)$

$\mathrm{CF}_{2} \mathrm{Cl}_{2} \rightarrow \mathrm{CF}_{2} \mathrm{Cl}+\mathrm{Cl}\left(\mathrm{Cl}^{+}, \mathrm{CF}_{2} \mathrm{Cl}^{+}\right)$

$\mathrm{CF}_{2} \mathrm{Br}_{2} \rightarrow \mathrm{CF}_{2} \mathrm{Br}+\mathrm{Br}\left(\mathrm{Br}^{+}, \mathrm{CF}_{2} \mathrm{Br}^{+}\right)$

$\mathrm{CHF}_{2} \mathrm{Cl} \rightarrow \mathrm{CF}_{2}+\mathrm{HCl}\left(\mathrm{HCl}^{+}, \mathrm{CF}_{2}^{+}\right)$

$\mathrm{CHFCl}_{2} \rightarrow \mathrm{CFCl}+\mathrm{HCl}\left(\mathrm{HCl}^{+}, \mathrm{CFCl}^{+}\right)$

$\mathrm{CFCl}_{3} \rightarrow \mathrm{CFCl}_{2}+\mathrm{Cl}\left(\mathrm{Cl}^{+}, \mathrm{CFCl}_{2}^{+}\right)$

$\mathrm{LFCl}+\mathrm{Cl}\left(\mathrm{CFCl}^{+}\right)$

$\mathrm{CHClCF}_{2} \rightarrow \mathrm{C}_{2} \mathrm{~F}_{2}+\mathrm{HCl}\left(\mathrm{HCl}^{+}\right)$

$\longrightarrow \mathrm{CHCF}_{2}+\mathrm{Cl}\left(\mathrm{CHCF}_{2}^{+}\right)$

$\mathrm{C}_{2} \mathrm{HCl}_{3} \rightarrow \mathrm{C}_{2} \mathrm{HCl}_{2}+\mathrm{Cl}\left(\mathrm{C}_{2} \mathrm{HCl}_{2}^{+}\right)$

$\mathrm{CF}_{3} \mathrm{CF}_{2} \mathrm{Cl} \rightarrow \mathrm{CF}_{3} \mathrm{CF}_{2}+\mathrm{Cl}\left(\mathrm{Cl}^{+}, \mathrm{C}_{2} \mathrm{~F}_{4}^{+}\right)$

$\mathrm{L}^{2} \mathrm{CF}_{3}+\mathrm{CF}_{2} \mathrm{Cl}\left(\mathrm{CF}_{2} \mathrm{Cl}^{+}\right)$

$\mathrm{CH}_{3} \mathrm{CF}_{2} \mathrm{Cl} \rightarrow \mathrm{CH}_{2} \mathrm{CF}_{2}+\mathrm{HCl}\left(\mathrm{HCl}^{+}, \mathrm{CF}^{+}\right)$
Absorption Frequency $\left(\mathrm{cm}^{-1}\right)$

1106

1082

1076

1098,923

1090

1116,1160

1070

1090

970

930

982

963
Exciting Frequency $\left(\mathrm{cm}^{-1}\right)$

1090.0

1078.6

1073.3

$1089.0,925.1$

1084.6

1082.3

1055.6

1074.6

967.7

$25^{\circ} \mathrm{C}$

929.1

$80^{\circ} \mathrm{C}$

978.5

$25^{\circ} \mathrm{C}$

956.2
Beam Nozzle

Temperature ${ }^{\circ} \mathrm{C}$

$240^{\circ} \mathrm{C}$

$25^{\circ} \mathrm{C}$

$25^{\circ} \mathrm{C}$

$25^{\circ} \mathrm{C}, 310^{\circ} \mathrm{C}$

$25^{\circ} \mathrm{C}$

$280^{\circ} \mathrm{C}$

$290^{\circ} \mathrm{C}$

$25^{\circ} \mathrm{C}$

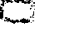

2

$-$

e

$$
-
$$

$-$ 
Table 1 (Continued)

Molecule, Fragments

and Observed Ions

$$
\begin{aligned}
& \mathrm{CH}_{3} \mathrm{CCl}_{3} \rightarrow \mathrm{CH}_{2} \mathrm{CCl}_{2}+\mathrm{HCl}\left(\mathrm{HCl}^{+}, \mathrm{CH}_{2} \mathrm{CCl}^{+}\right) \\
& \mathrm{SF}_{6} \rightarrow \mathrm{SF}^{5}+\mathrm{F}\left(\mathrm{SF}_{3}{ }^{+}, \mathrm{SF}_{2}^{+}\right) \\
& \mathrm{N}_{2} \mathrm{~F}_{4} \rightarrow \mathrm{SF}_{4}+\mathrm{NF}_{2}\left(\mathrm{NF}_{2}^{+}, \mathrm{SF}^{+}\right)
\end{aligned}
$$

Absorption -1 Exciting -1 Beam Nozzle

Frequency $\left(\mathrm{cm}^{-1}\right)$ Frequency $\left(\mathrm{cm}^{-1}\right)$ Temperature ${ }^{\circ} \mathrm{C}$

1075

1073.3

$25^{\circ} \mathrm{C}$

948

944.2

$25^{\circ} \mathrm{C}$

998

975.9

$25^{\circ} \mathrm{C}$ 
This report was done with support from the United States Energy Research and Development Administration. Any conclusions or opinions expressed in this report represent solely those of the author(s) and not necessarily those of The Regents of the University of California, the Lawrence Berkeley Laboratory or the United States Energy Research and Development Administration. 